\title{
Citizens' Constitutional Rights Regarding Habitable and Wholesome Environment: Towards a Law State that Protects the Environment
}

\author{
Nyoman Satyayudha Dananjaya* \\ The Graduate School of East Asian Studies Yamaguchi University, Japan \\ Kazuhiko Fuchikawa** \\ The Graduate School of East Asian Studies Yamaguchi University, Japan \& \\ The Graduate School of Law Osaka City University, Japan
}

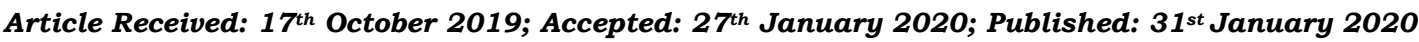

\begin{abstract}
This paper aims to examine the protection of the environment in Indonesia which is part of the realization of a law state that guarantees the constitutional rights of its citizens. It is a legal research that reviews Indonesian constitutional and statutory provisions, besides adding a comparative perspective from a Japanese Constitution and legal system. It is found that the concept of a law state in Indonesia does not specifically follow the concept of a law state like what is meant in "rechtsstaat" or "the rule of law". It has peculiar characteristics which indeed seem to adopt the noble values of those two concepts which clearly confesses in the constitution along with the elements and characters stated in it. One of the most prominent characteristics of a law state is the recognition and protection of human rights. In the Indonesian Constitution 1945, human rights as the fundamental rights of human beings have been arranged and compiled which is legally legitimized become constitutional rights. Among human rights, rights related to the environment include essential rights in array of international human rights formulations. Article 28 letter $H$ of the Indonesian Constitution 1945 expressly states the rights to habitable and wholesome environment for citizen. The protection form can be a normative arrangement in the constitution or in a formal juridical through legislation. Protection of citizens' constitutional rights related to the environment is faced with due process of environmental protection that requires consistency in order to achieve the intention and direction of the Indonesian law state itself.
\end{abstract}

Keywords: A Law State; Citizens' Constitutional Rights; Environmental Protection; Indonesia; Japan.

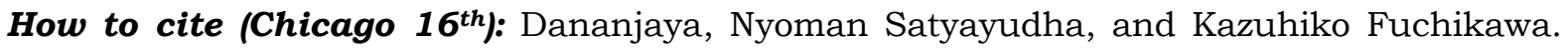
“Citizens' Constitutional Rights Regarding Habitable and Wholesome Environment: Towards a Law State That Protects the Environment." Udayana Journal of Law and Culture 4, no. 1 (2020): 81-103. https://doi.org/https://doi.org/10.24843/UJLC.2020.v04.i01.p05 .

doi: https://doi.org/10.24843/UJLC.2020.v04.i01.p05

\footnotetext{
* Email/Corresponding Author: g504sn@yamaguchi-u.ac.jp

** Email : kf@yamaguchi-u.ac.jp
} 


\section{Introduction}

The concept of law state has been thought of by philosophers and legal experts. This concept is built by putting the law as a functional and fairness system. The thought of a law state began when a Greek philosopher Plato presented the concept of good state administration, starts with his book named Politeia (The Republic) ${ }^{1}$ and ends with Nomoi (The Laws) ${ }^{2}$ described as regards the state and the law in relation to realizing the concept of the state and the implementation of an ideal state would only be able to be governed by laws. From the philosopher's thought, in ancient European civilization times, the law has been placed as a central point in people's lives in a region (state), indicating that the law in a state occupies an important position. A law state is a state that stands on a legal basis to organize the life of the nation and the state of its citizens as well as the relationship between the state and its citizens. It is understandable that every citizen is a human being wherever they are always bound by the rules (laws) or norms of life.

The affirmation of a state as a law state is put on the presence or absence of a constitution, a defining affirmation that the constitution is a special national document and at the same time is a legal and political document. The constitution contains the basic framework, structure, functions and rights of state institutions, the relations between the state and its citizens regarding citizens' constitutional rights and supervision of the implementation of good governance. This is what the so-called constitutionalism is descriptive of complex concepts, embedded in historical experience, which subdue officials who use government power restricted by a higher law. This also means that if a state that is restricted by constitutional law in using its power, then the administration of its government will be orderly and prosperous. There is a perception in the modern state which is then accepted as the fundamental principle for governance that a constitution that is not based on constitutionalism is not considered as a veritable constitution. ${ }^{3}$ Therefore, every independent state has a constitution, which constitution is likened to a reflection of the soul of

${ }^{1}$ The Republic is a Socratic dialogue written by Plato concerning justice, character of the equitable city-state, and the just man. See Plato, The Republic of Plato (London: Francis Macdonald Cornford trans, Oxford University Press 1941), 41-139, 265.

2 The Laws is Plato's final and extensive dialogue. The conversation described in the work's twelve books begins with the purpose of government, examines the origins of government and the merits of different constitutions, analyzes the correct method for legislating law, on midway of the books describing the legal positions, introduces criminal law include how determining a punishment and ends with legal code. The Laws afterthought on the ethics of government and law have established it as a classic of political philosophy. See Plato, The Laws of Plato (London: Thomas L. Pangle trans., The University of Chicago Press 1980), 3-88, 137-77, 245-79.

3 Ito M, "The Modern Development of Law and Constitution in Japan," in Japan Legal System: Text and Material, ed. Meryll Dean, (London: Cavendish Publishing Limited 1997), 520-521. 
a state. To the extent of achieving the ideals of a law state, the substance of the constitution needs to be implemented. One of the substances contained in the state constitution is a regulation related to human rights.

In the Japanese Constitution, Japan is a state that places human rights as an important pillar. The protection of the environment is one of the main agendas that continue to be maintained. Japan strongly supports UN activities in the human rights field, believing that all human rights are universal. ${ }^{4}$ In the Japanese Constitution, the Article 11 states that people must not be obstructed in obtaining human rights. Human rights are guaranteed by the Constitution. Likewise, in the Article 25 states that all people have the right to maintain a minimum standard of healthy and cultured living. In all spheres of life, the State must use its endeavors to promote and expand social welfare and security, and public health. This is then implemented through environmental policy and protection established in various laws and regulations which then begin with the issuance of the Basic Environment Law and the Basic Environment Plan.

Fulfilling and protecting human rights (as a fundamental rights of human beings) is an absolute element that must exist in the constitution. ${ }^{5}$ The human rights were published as a form of state recognition and as a guarantee of state protection for the rights of citizens, so that the rights are legally legitimate. Thus, it will bring up a legal consequence that any form of policy and legislation that is enacted may not violate or negate these rights. Human rights are rights that universally recognized in intercommunication of nations as part of the international community. Human rights are inherent rights of all humans, regardless of our nationality, place of residence, gender, national origin or ethnicity, color, religion, language or another status. We are all equally entitled to our human rights without discrimination. This is the essence of articles 1 and 2 of the Universal Declaration of Human Rights initiated on 10 December 1948. Since its declaration, several human rights in the Universal Declaration of Human

${ }^{4}$ See Ministry of Foreign Affairs of Japan, Human Rights, Humanitarian Assistance, Refugees, available at https://www.mofa.go.jp/policy/human/index.html

${ }^{5}$ As a comparison, in Japan, in the context of Japanese history, although it is usual to speak of the 1946 Constitution as the new constitution which in global context it is one of the more long-lived and enduring constitution, there are three pillars of the present constitutional framework; Popular sovereignty, Pacifism and Protection of fundamental human rights are based upon the foundation of respect to the rule of law and are guaranteed by the supreme court through the use of judicial review...this is demonstrated by the fact that fundamental human rights are protected against the arbitrary exercise of government power... See Meryll Dean, Japanese Legal System: Text and Material (Cavendish Publishing Limited 1997), 506. See Also Hiroshi Oda, Japanese Law (New York, Oxford University Press $3^{\text {rd }}$ Ed.2009), 28-30 mentioned that there is an extensive bill of rights in the constitution and respect for fundamental human rights is one of the three fundamental principles underlying the present constitution of Japan. Fundamental human rights guaranteed by the constitutions are coffered upon the people as eternal and inviolable rights. 
Rights or commonly called the $1948 \mathrm{UDHR}^{6}$, it has been gradually adopted by countries as a normative recognition which then mainly placed in their constitution. When human rights are stated in the constitution of a state, hence, human rights are constitutional rights. ${ }^{7}$

This paper aims to examine the protection of the environment in Indonesia which is part of the realization of a law state that guarantees the constitutional rights of its citizens. Furthermore, this paper questions who has constitutional rights? are there certain requirements to have constitutional rights? Likewise, the right to a good and healthy environment as one of the constitutional rights of citizens. Does the inclusion of the right to a good and healthy environment into the constitution as a constitutional right for Indonesian citizens can guarantee the protection of the citizens' constitutional rights? Nevertheless, what is stated in the constitution as a constitutional right can be interpreted that the implementation of protection and law enforcement will run well?

As an introduction, this paper describes the concept of a law state, constitution and human rights in the constitution as constitutional rights. This paper also explains the essence of the ideals law state by giving state guarantees to the protection of its citizens' constitutional rights. In result and discussion section will elaborate on the conceptional framework of Indonesian law state and the citizen's constitutional rights in the conception of Indonesian law state. After that, the discussion will then elucidate the protection of citizens' constitution rights related to the habitable and wholesome environment as an issue to examine. Furthermore, this paper will compare the constitutional perspectives for environmental protection in Indonesia and Japan before giving a conclusion as to the last part of this paper.

\section{Result and Discussion}

\subsection{The Conceptional Framework of Indonesian Law State}

In a law state, the existence of a constitution is very important. The constitution and the state are likened to two things that inseparable existence. This is a logical consequence of the fact that without a

6 The Universal Declaration of Human Rights (UDHR) is a milestone document in the history of human rights. Drafted by representatives with different legal and cultural backgrounds from all regions of the world, the Declaration was proclaimed by the United Nations General Assembly in Paris on 10 December 1948 (General Assembly resolution 217 A) as a common standard of achievements for all peoples and all nations. It sets out, for the first time, fundamental human rights to be protected universally, available at www.un.org/en/universal-declaration-human-rights/.

7 Jimly Asshidiqie, Pengantar Ilmu Hukum Tata Negara [The Introduction of Constitutional Law] 134 (Jakarta, Konstitusi Press 2006). See also Gerald L. Neuman, Human Rights and Constitutional Rights: Harmony and Dissonance Stan. L. Rev. 55 (2003): 1863-1900, $1865 \ldots$ and will refer to individual rights protected by national constitution as "constitutional rights". 
constitution, a state cannot be formed due to the existence as a state fundamental law. The constitution is an assurance in realizing a law state, and in a law state, the importance of the existence of a constitution as a state fundamental law because the state which is regulated by the law brings up to a conception of the law state.

In general, the conception of law state is always oriented towards two different legal systems, namely the common law legal system and the civil law legal system. These two legal systems use different terms, namely "rechtsstaat" and "the rule of law". 8 In the Continental European legal system, the term rechtsstaat is also referred to by other terms such as the concept of legality or L'État de droit. The term of the rule of law became popular in Anglo-American legal system after the publication of Albert Venn Dicey book in 1885.9

The terminology used to refer a law state at that time, "rechtsstaat" and "the rule of law" has a different historical background. In Europe, rechtsstaat emerges rapidly and comprehensively which rests on a legal system known as the civil law legal system. The rechsstaat, however, was more complex and regarded government both "as the representative of the general will (restricting the administration to the application of the enacted law) and as having its own particular will (based on the government's subjective right to command). ${ }^{10}$ The genuine concept of rechtsstaat by establishing government legitimacy through compliance with laws. ${ }^{11}$ Towards the end of the 19th century, the concept of rechtsstaat changed and requires substantive legitimacy such as the protection of human rights. ${ }^{12}$ Conversely the rule of law has developed gradually which then relies on common law legal systems. These two terminologies (rechtsstaat and the rule of law) in principle lead to one main understanding and meaning, namely a law state. Both terminologies are meant to view the law as an effective means of managing the nation and state life. However, there are many differences that clearly be seen from both rechtsstaat and the rule of law. Rechtsstaat, in principle, contains basic features including the protection of human rights, the separation or division of powers of state institutions in order to guarantee the implementation of the state power, and the existence of administrative justice. The rule of law in principle

\footnotetext{
8 See James R. Silkenat, James E. Hickey Jr., Peter D. Barenboim, eds. The Legal Doctrines of the Rule of Law and the Legal State (Rechsstaat), (Switzerland: Springer, 2014), 15-104. 145-151.

${ }^{9}$ See Albert Venn Dicey, Introduction to the Study of the Law of the Constitution, (London: Macmillan, $8^{\text {th }}$ ed. 1915), 107-122.

10 Mireille Hildebrandt, "Justice and Police: Regulatory Offenses and the Criminal Law." New Criminal Law Review: In International and Interdisciplinary Journal 12, no. 1 (2009): 43, 59.
}

11 Ibid.

12 Ibid., 56. 
contains basic characteristics such as the existence of the supremacy of law, equality before the law and a guarantee of protection of human rights. The traditional Anglo-American concept of the rule of law is also more precisely defined as consisting of two interdependent components: 1) the obligation of citizens to comply with the law and 2) government compliance with the law. ${ }^{13}$ In a law state that embraces rechtsstaat, it is clearly seen how important administrative justice as a differentiating tool to other legal systems. In a law state that adheres to the rule of law, places the importance of equality before the law.

The history of Indonesian constitutionality describes the concept of a law state which is affirmed in the constitution. This means that the concept of a law state is more directed towards the realization of a prosperous state and provides protection to the nation. Thus, the decent implementation of the state constitution can provide guarantees to embody the state based on the law.

Wheare defines the constitution of a state as "... the state's governance system, a set of rules which establish and govern the state". ${ }^{14}$ Thomas Paine reveals more broadly that "a constitution is not the act of a government, but of a people constituting a government, and a government without constitution is power without right... a constitution is something precedes the government and a government is only a constitutional creature. 15

Although there are several constitutions that have been implemented in Indonesia, there have been replaced/amended, but the affirmation of Indonesia as a law state is always stated in the constitution. This shows that Indonesia itself views the importance of the concept of a law state in organizing the life of the nation and state. Both in the constitution that was once implemented in Indonesia ${ }^{16}$ such as the Indonesian Constitution 1945 , the Indonesian Federal Constitution 1949 and the Indonesian Provisional Constitution 1950 until the re-enactment of the Indonesian Constitution 1945 to the Amended Indonesian Constitution 1945, the concept of a law state always received its own emphasis in the constitution.

In the Indonesian Constitution 1945 before the amendment, both in the Preamble and the Body or its articles, no formulation or term of a law

13 See Michel Rosenfeld, The Rule of Law and the Legitimacy of Constitutional Democracy, S. Cal. L. Rev. 74 (2001), 1307, 1335-36 ed.1966), 1.

14 K.C Wheare, Modern Constitutions (New York: Oxford University Press, $2^{\text {nd }}$

15 Thomas Paine, The Rights of Man 1971-1972, ed. H Collins, (Penguin Classics 1969), 93.

16 The Indonesian Constitution 1945 (commonly called the Constitution of the Republic of Indonesia Year 1945) remained in effect until it was replaced by the Federal Constitution on December 27, 1949. Then replaced by the Provisional Constitution on August 17, 1950. Finally, at 5 July 1959 President Sukarno issued a decree returning to the 1945 Indonesian Constitution. 
state was found. The term of a law state is only found in the Explanatory Section, namely "The State Government System", stated that "Indonesia is a state based on law (rechtsstaat)" and described by a sentence "The State of Indonesia is based on law (rechtsstaat), not based on mere power (machtsstaat). The expression that mentioned state based on law (rechtsstaat) is a term or formula often used in the Continent of Europe. Therefore, it indicates that the substance of the Indonesian law state is inseparable from the influence of the notions, characteristics, and elements of the law state known in Continental European countries. Whereas, in the Amended Indonesian Constitution 1945, the affirmation of the Indonesian law state was stated in the third amendment to the Indonesian Constitution 1945, in Article 1 subsection (3) which states that "Indonesia is a law state". However, no explanation is found regarding the actual law state that Indonesia currently adheres to, whether it is a law state in the sense of "rechtsstaat" or a law state in the sense of "the rule of law" or even a law state with its own characteristics. When looking at the statements regarding a law state as outlined in the Indonesian Constitution 1945 on the third amendment, where no further elaboration is found in the explanation section, it can be understood that a law state adopted by Indonesia has its own character. The application of the principle of a law state in Indonesia can be said to be carried out without referring directly to one concept of a law state as intended in "rechtsstaat" or "the rule of law". The concept of a law state in Indonesia applies the principles in the general concept of a law state outlined in "rechsstaat" and "the rule of law". Thus, it is more accurately mentioned as "the Indonesian Law State". Based on its implementation, important elements of the law state are well realized. The Indonesian law state, in general, explained the administration of the state based on applicable laws and regulations, the protection of human rights as a citizen constitutional right 17 , separation or division power, 18 the implementation of popular sovereignty, ${ }^{19}$ and the existence of a state administrative court ${ }^{20}$ are still used as a basis in realizing a law state in

17 As formulated in the Second Amendment to the Indonesian Constitution 1945, there are 27 propositions concerning human rights contained therein, the provisions concerning human rights have received constitutional assurance contained in Chapter XA concerning human rights Articles 28A-28J and Chapter XI concerning Religion Article 29 subsection (2) of the Second Amendment to the Indonesian Constitution 1945.

18 The division of power referred in the concept of the law state are legislative, executive and judicial power. In Indonesian Constitution 1945, legislative power can be seen in the provisions of Chapter VII concerning the people's representative council, and Chapter VII A concerning the regional representative council. Carrying out the executive powers is contained in the provisions of Chapter III concerning the power of state government and with regard to the judicial power in the provisions of Chapter IX concerning judicial power.

19 The Constitution of Indonesia 1945, Chapter I concerning State Form and Sovereignty, Article 1, subsection (2) of the Indonesian Constitution 1945.

${ }^{20} \mathrm{Ibid}$, Chapter IX concerning Judicial Power, Article 24, subsection (2). 
Indonesia. The Indonesian law state also applies the principle in "the rule of law" concept such as the supremacy of law which requires that the law must be upheld which can be affirmed by the sentence that the law is commander, the administration of the state is based on law not by men/individual. In addition, the principle of equality before the law ${ }^{21}$ and the principles of independence and impartially of the judiciary to realize the due process of law are also determined as elements of the Indonesian law state. ${ }^{22}$

The elaboration of the principles of the law state contained in the Indonesian constitution, the application of the law state principle in Indonesia is based on its own principle which may not always be in full alignment with the principles of the law state as it was known in the early birth of the concept of the law state. Re-formulation of the main idea of the concept of law state is interpreted as a form of dynamics or the development of a law state at the present era. Even so, it will be the main pillars that support the upholding of a modern law state that can realize the goals and ideals contained in the constitution, namely justice and prosperity.

\subsection{The Citizens' Constitutional Rights in Indonesian Law State Conception}

Jimly Asshiddiqie argues that one of the absolute elements that must exist in a law state itself is regarding the fulfillment of human rights. Therefore, Indonesia which is a state based on law, has an obligation to guarantee and protect its citizens. ${ }^{23}$ In the Constitution of Indonesia 1945, it clearly states the rights of citizens, hereinafter referred to as constitutional rights. In the implementation of the constitution in Indonesia, human rights are manifested in a legal legitimacy become constitutional rights. I Dewa Gede Palguna mentioned 24 the use of the term "human rights" has a universal spectrum with a broader scope than the term "constitutional rights". Constitutional rights have a domestic scope that applies to the positive law of a state. The development of human rights at the international level provides an impetus for the recognition of its existence at the national level as constitutional rights.

However, it does not mean that there is a dichotomy among them. Human rights and constitutional rights have similar functions, substances, and structures. ${ }^{25}$ The function of both is limiting government power and

${ }^{21}$ Ibid, Chapter X concerning Citizen and Population, Article 27, subsection (1).

22 Ibid, Chapter IX concerning Judicial Power, Article 24, subsection (1).

23 Jimly Assiddiqie, Pengantar Ilmu Hukum Tata Negara, Cetakan Kedua, [Introduction to Constitutional Law], (Jakarta: Rajawali Press $2^{\text {nd }}$ ed. 2010), 343.

24 I Dewa Gede Palguna, Pengaduan Konstitusional: Upaya Hukum Terhadap Pelanggaran Hak-Hak Konstitusional Warga Negara [Constitutional Complaints: Legal Efforts Against Violations of Citizens' Constitutional Rights], (Jakarta: Sinar Grafika 2013), 131.

25 See Stephen Gardbaum, Human Rights as International Constitutional Rights, The Eur J. of Int'r Law 19, no.4 (2008): 749-768, 750-751. 
protecting the basic rights of every citizen. ${ }^{26}$ Substantially, both of them contain basic rights such as economic, social, cultural, civil and political rights, besides the protection of minority group rights and environmental protection. ${ }^{27}$ In addition, human rights and constitutional rights also have a similar structure where there is a distinction between rights that can be restricted (derogable rights) and cannot be restricted or reduced by the element of fulfillment (non-derogable rights). ${ }^{28}$

Constitutional rights ${ }^{29}$ are assertively defined and written in a state constitution as the supreme law of the land, meaning that any other laws in contradiction with it are unconstitutional and thus declared as invalid. The form of legitimacy is found in the body of the Indonesian Constitution 1945. The norms contained in the Indonesian Constitution 1945 not only regulate the relations between state institutions that giving rise to the constitutional authorities but also regulate relations between the state and its citizens in the context that is dealing with the constitutional rights of its citizens. The Indonesian Constitution 1945 determines the structure, functions, powers, restrictions on the government and the individual freedoms, rights, and obligations which will be protected and enforced by state institutions that have a constitutional authority. In this connection, the citizens' rights determined in the Indonesian Constitution 1945 as constitutional rights are a form of protection for citizens from state actions in the administration of the state.

Addressing the citizens' constitutional rights, it can be explained that the citizens' constitutional rights are rights granted by the state given due to legitimated citizenship status in the Indonesian Constitution 1945. The citizenship of an individual determines many aspects of the relation which a person has with the state of which he or she is a national, and with other states. ${ }^{30}$ This citizens' constitutional rights are the result of legitimacy recognized in the constitution and other legislations. Rights of citizens are rights granted by the state on citizenship status according to the laws and regulations.

26 Gerald L. Neuman, op.cit., 1863-1865.

27 Stephen Gardbaum, op.cit., 750.

28 See Stephen Gardbaum, The 'Horizontal' Effect of Constitutional Rights, Mich. L. Rev 102, (2003): 387-458. Note: the term derogable rights is defined as rights that can still be deferred or limited (reduced) fulfillment by the state under certain conditions. Meanwhile the term non derogable rights means that there are rights that cannot be deferred or limited (reduced) by the state, even though in an emergency.

29 The Indonesian Constitution 1945 does not provide the meaning/definition of constitutional rights. In Indonesian positive law, the meaning/definition of constitutional rights is determined in Act Number 24 Year 2003 jo. Act Number 8 Year 2011 concerning Constitutional Courts where constitutional rights are rights that are regulated in the Indonesian Constitution 1945.

30 A.W. Bradley And K.D. Ewing, Constitutional and Administrative Law (Pearson Education Limited $13^{\text {th }}$ ed. 2003), 425. 
In achieving the ideals of state, one of the substances contained in the state constitution is the regulation related to human rights. A state that adheres to the rule of law or rechtsstaat (law state), one of the elements that must absolutely exist is the fulfillment of human rights (as a fundamental rights). The human rights are as a form of state recognition and state protection for the basic rights of citizens, so that the rights are legally legitimate. The consequence is that any applicable form of policy and legislation may not violate or nullify human rights (as fundamental rights).

Constitutional rights are also related to the state's recognition of the subject of constitutional rights, namely citizens. An Indonesian Citizen is a person who legally recognized and legalized by Indonesian laws and regulations. Therefore, as an Indonesian citizen, they have the same and equal rights. Constitutional rights can be seen as reciprocity of constitutional obligations, so that constitutional rights and constitutional obligations cannot be separated, where it can be explained that the existence of constitutional rights is due to the existence of constitutional obligations raised of the Indonesian Constitution 1945. Constitutional obligations are the consequence of citizens in their position on enforcing actions that are required by the state. Citizens' constitutional rights are acquiring protection from the state actions in state administration due to guaranteed by the state constitution. Such rights must not be violated and become a barrier to state actions.

\subsection{The Protection of Citizens' Constitutional Rights}

Assignation of the rights to habitable and wholesome environment has an important meaning and rights as citizens' rights. In the history of its development, rights to the environment are a human right. A comprehension that can be traced and also be juxtaposed with Article 25 of the UDHR ${ }^{31}$ which states, "everyone has the right to a standard of living adequate for the wholesome and well-being of himself and of his family". Whereas in Article 12 paragraph (1) ICESCR 32 is affirmed, "the states in this

31 The Universal Declaration of Human Rights (UDHR) then has been adopted by the United Nations General Assembly on 10 December 1948 as Resolution 217 at the Palais de Chaillot in Paris. It consists 30 articles affirming an individual's rights, it has been elaborated in international treaties, regional human rights instruments, national constitutions, and other laws. It was the first step of formulating process of the International Bill of Human Rights which was completed in 1966 and a sufficient number of countries had ratified.

32 On 16 December 1966 through GA. Resolution 2200A (XXI), a multilateral treaty called the International Covenant on Economic, Social and Cultural Rights (ICESCR) adopted by the United Nations General Assembly and came in force from 3 January 1976. In General Comment 14, paragraphs 11-12, In connection with habitable and wholesome environment mentioned that "states must protect this right by ensuring that everyone within their jurisdiction has access to the underlying determinants of health, such as clean water, sanitation, nutrition and housing, and through a comprehensive system of healthcare, which is available to everyone without discrimination, and economically 
covenant recognize the right of everyone to relish the utmost standard of physical and mental health". Signify, the life needs of Indonesian citizens must also be fulfilled according to adequate measures both for their health and other matters related to the support of one's life. More broadly, this norm is reinforced by its meaning as one of the state goals and ideals (staatliche ideale) in the Preamble on $4^{\text {th }}$ Paragraph of the Constitution of Indonesia 1945, namely, to protect the entire Indonesian nation.

This provision implies that every citizen has the right and constitutional guarantee to live and obtain habitable and wholesome environment to grow and develop. The meaning of habitable and wholesome environment can be seen in its philosophical foundation (the highest law of the land). It was mentioned that habitable and wholesome environment is the fundamental rights of every Indonesian citizen as mandated in Article 28 $\mathrm{H}$ of the Constitution of Indonesia 1945. Thus, the recognition of the rights to habitable and wholesome environment as human rights then becomes a constitutional right for every citizen in Indonesia. Therefore, the state (through state administrators) and all stakeholders are obliged to protect the environment in the implementation of environmentally sustainable development and for the benefit of mankind at present and in the future.

Recognizing a constitutional right to environmental protection would similarly curtail the power of a legislature to permit tampering with the environment. This has not assumed that the right of the environment is so important that a court will take the step necessary to assure its protection. The judicial process, problems complexity, likewise conformity of institutions for expressing values and devising solutions are worthy of the most serious consideration in determining the existence and scope of any constitutional right to a livable environment. But such considerations do not necessarily preclude the right's existence nor, at this point, delimit its scope. 33

The court will find that the state action requirement is met the erect manageable judicial standard and impose an affirmative duty on the state to regulate private interest all in the name of the environment. ${ }^{34}$ Protection of constitutional rights can be proven by the existence of constitutional rights as a limitation for the actions of the state power holder which leads to strict legal mechanisms in protecting the constitutional rights of citizens. There are mechanisms that can be used to provide protection against constitutional rights through litigation as follows:

accessible to all".

33 See Ronald E. Klipsch, Aspects of a Constitutional Right to a Habitable Environment:Towards an Environmental Due Process, Ind. L.J. 49 (1974): 204-206.

34 See John Y. Pearson Jr., Toward A Constitutionally Protected Environment, Va. L. Rev. 56, (1970): 458-86, 470-75. 
a. Through the Constitutional Court

There are at least 5 functions attached to the existence of a constitutional court and are carried out through its authority, one of which is as a protector of the citizens' constitutional rights. ${ }^{35}$ The Constitutional Court is a state institution that has the competence to adjudicate the review of the constitutionality of the Act as an effort to enforce the citizens' constitutional rights over the negligence of the legislative and executive power in drafting the Act that violates the constitutional rights of citizens. Hans Kelsen stated that the application of the constitutional rules concerning legislation can be effectively guaranteed only if an organ other than the legislative body is entrusted with the task of testing whether a law is constitutional, and of annulling it if according to the opinion this organ it is "unconstitutional". ${ }^{36} \mathrm{He}$ argues there is a special organ established for this purpose, for instance, a special court, a so-called "constitutional court". In Indonesia, through constitutional court, the efforts to assure the constitutionality are by both judicial review and constitutional complaint. Judicial review and constitutional complaint must be distinguished because the judicial review is an attempt to examine the constitutionality of the law enacted in society, while a constitutional complaint is an attempt to examine the constitutionality of the state power holder actions. 37 These two procedures are indeed legal efforts that can be pursued in defending citizen constitutional rights. However, judicial review can be seen as a legal procedure in examining the constitutionality in a narrow sense. It is different from a constitutional complaint. If it is related to the concept of a law state and sovereignty, a constitutional complaint is a legal procedure in the broad sense that protects citizen rights.

\section{b. Through the State Administrative Court}

The hearing procedural in State Administrative Court is used as one of the legal efforts to protect the constitutional rights of citizens where there is a violation of the citizens' constitutional rights because of the issuance of the administrative decree by the administrative institutions or officer due to contrary to the laws and regulations. There are 3 (three) meanings contrary to the laws and regulations, namely:

a) Contrary to the provisions of the formal laws and regulations;

b) Contrary to the provisions of material laws and regulations;

35 Nilwan Wilze Ananda Zen, Untung Dwi Hananto, and Amalia Diamantina Jaminan Hak-Hak Konstitutional Warga Negara (the Protector of Citizen Constitutional Right) dengan Implementasi Constitutional Complaint Melalui Mahkamah Konstitusi di Negara Republik Indonesia, Diponegoro L. Rev 5, no. 2 (2016): 1-24.

36 See Hans Kelsen, General Theory of Law and State, (New York: Anders Wedberg trans., Russell \& Russell 1945), 157

37 I Dewa Gede Palguna, op.cit, 153. 
c) Issued by an unauthorized State Administration Institutions or Officer. 38

c. Through the General Court

In the procedure of the general judiciary through general court, there are two types of cases which are the absolute competence of the court in examining and adjudicating cases, namely courts for criminal cases and courts for civil cases. In the civil cases, this legal mechanism can be pursued if one party feels harmed conducted by another party so that one party to be impaired by its constitutional rights. While in a criminal case, the case is between individuals and/or legal entities for the actions of one of the parties who have fulfilled the elements of violations of criminal law provisions. The protection of the constitutional rights of citizens can be done through filing claims and/or lawsuits in the first instance court, appeals in the high court, cassation and judicial review in the supreme court. In general, the purpose of this judicial system contains the principle of protecting human dignity. 39

\subsection{The Constitutional Perspective of Environmental Protection in Indonesia and Japan: A Brief Understanding \\ 2.4.1 Environmental Protection in Indonesia}

Habitable and wholesome environment as a citizens' constitutional rights contains environmental meanings that can enable humans to develop optimally, in harmony and balance. The existence of this assurance gives the possibility for everyone to demand the state that habitable and wholesome of their environment needs to be considered and improved continuously. Therefore, the state has an obligation to provide habitable and wholesome environment for its citizens and continuously make efforts to protect and manage the environment.

The recognition of the right to habitable and wholesome environment in Indonesia cannot be separated from international influences because Indonesia is part of a state in the world. Internationally, the right of habitable environment is contained in the Stockholm Declaration, the second part of the Stockholm Declaration 40. During the preparation, delegates at the conference thought the Stockholm Declaration should begin

38 See Phillipus M. Hadjon, Pengantar Hukum Administrasi Negara Indonesia [Introduction to Indonesian State Administration Law], (Yogyakarta: Gadjah Mada University Press, 2005), 326-327.

39 I Dewa Gede Palguna, loc.cit.

40 The United Nations Conference, having met at Stockholm from 5 to 16 June 1972, having considered the need for a common outlook and principles to inspire and guide the peoples in the preservation and enhancement of the human environment. On the report proclaimed 26 Principles, commonly called Declaration of the United Nations Conference on the Human Environment in 21 $1^{\text {st }}$ Plenary Meeting on the $16^{\text {th }}$ of June 1972. 
with the affirmation that every human being has the right to a decent or wholesome environment.

Principle 1 Stockholm Declaration mentioned ${ }^{41}$ :

"Man has the fundamental right to freedom, equality and adequate conditions of life, in an environment of a quality that permits a life of dignity and well-being, and he bears a solemn responsibility to protect and improve the environment for present and future generations...”.

Links to human rights and environmental protection, the first sentence has given interpretations. Narrowly, it restates pre-existing international human rights of liberty, equality and an adequate standard of living, but innovates in adding that the implementation of these rights depends upon environmental conditions, reflecting the perception that environmental degradation takes effect on the human rights. Broadly, Principle 1 Stockholm Declaration supported a growing movement to recognize the right to a habitable and wholesome environment as a human right.

In the Article 28 letter $(\mathrm{H})$ of the Indonesian Constitution 1945 states that every person has the right to live physically and mentally, live and get habitable and wholesome environment and is entitled to health services. The mandatory of the Indonesian Constitution 1945 clearly considers that the need to get a wholesome environment is one of the fundamental rights. The state is obliged to provide protection and guarantee for habitable and wholesome environment. Therefore, the state must have a strong authority in managing and protecting the environment. The constitutional clearly inspires (obligates) the need for the state to create a comprehensive rule that is oriented far ahead. The elaboration on the constitutionality of environmental protection along with the citizens rights to the environment are set forth in the environmental law. The Act Number 32 Year 200942 concerning Environmental Protection and Management (hereinafter referred to Environmental Act) ${ }^{43}$ as a primary act of the environmental law in Indonesia is a legislation which is the implementation of the provisions of article 28 letter $(\mathrm{H})$ in the Indonesian Constitution 1945. It contains norm to

41 See Dinah Selton, Human Rights, Health \& Environmental Protection: Linkages in Law \& Practice, Health and Human Rights Working Paper Series No 1 A Background Paper for the World Health Organization. See also Dinah Selton Stockholm Declaration (1972) and Rio Declaration (1992), Oxford Public International Law, available at http:/ / opil.ouplaw.com/view/10.1093/law:epil / /9780199231690/law-9780199231690e1608\#law-9780199231690-e1608-div1-2.

42 This environmental act is applied in Indonesia as a replacement of the two previous environmental acts. The first, Act No. 4 Year 1982 concerning the Basic Provisions of Environmental Management, the second, the Act No. 23 Year 1997 concerning Environmental Management. This replacement occurred due to the argument and opinion at that time that the previous act had not been able to answer the challenges and environmental problems that occurred in Indonesia.

43 In Indonesia, informally, UUPPLH refer to this Environment Act because it is the abbreviation of Undang Undang Perlindungan dan Pengelolaan Lingkungan Hidup (The Environmental Protection and Management Act). 
settle environmental cases by using case settlement mechanisms through administrative law, civil law and criminal law procedures to provide protection and law enforcement efforts. Therefore, in all aspects of the environment, there will always be interconnection with basic rights whether with the scope of administrative, civil or criminal.

In the Environmental Act, it includes human elements and all their behavior, therefore, humans as environmental subjects have a role that includes rights and obligations as well as participating in environmental sustainability. The right to habitable and wholesome environment as a subjective right is the broadest form of citizen protection. What is called "subjective rights" in this context is the most extensive form of protection. Subjective rights provide legal rights to claim their interests in a livable environment, claims that can be upheld by legal procedures and must be respected. ${ }^{44}$ So that, the rights for habitable and wholesome environment as a fundamental right for citizen must be protected to get an environment that can affect the survival of humans and other living things that will be spared from environmental pollution and destruction.

In accordance with Article 65 paragraph 1 up to paragraph 5 of Environmental Act, it can be found that the rights which are contained in the environmental field are:

a. The rights to good environmental,

b. The rights to obtain environmental education,

c. The rights to access information, access to participation and access to justice in fulfilling the rights of habitable and wholesome environment,

d. The rights to submit proposals and/or objections for business plans and/or activities that are expected to have an impact on the environment,

e. The rights to have a role in environmental protection and management,

f. The rights to file complaints / file a sue due to environmental pollution and/or destruction.

The rights mentioned above can be grouped into two types of due process of right. First, substantive due process rights (substantive right to environmental quality in the form of rights to obtain habitable and wholesome environment). Second, procedural due process of right that includes the rights to get access for justice, the rights to participate, and the rights to file complaints/file a sue. However, the Court has not always distinguished substantive and procedural due process in setting forth such

44 Subjective rights are claims that are legally and lawfully recognized by legal subjects for certain legal objects. Therefore, when a legal subject acquires the right to an object as a real relationship with that object, that right is a subjective right See Heinhard Steiger et.al., Tendances Actuelles De La Politique Et Du Droit De L'environnement (The Fundamental Right to a Decent Environment, Trends in Environmental Policy and Law), IUCN-WWF (project No. 1244) 2-5 (1980). 
standards. The Court has maintained, in effect, that the due process clause empowers the judiciary to impose natural law limitations upon the conductregulating and enforcement. ${ }^{45}$

\subsubsection{Environmental Protection in Japan}

In Japan, protecting the rights of citizens to good, wholesome and livable environments is an important priority. Constitutional protection of these rights can be seen in the provisions of the Japanese constitution in Chapter III concerning Rights and Duties of People Article 11 states that the people must not be prevented from obtaining human rights. Human rights are guaranteed by the Constitution which is given to present and future generations as perpetual and inviolable rights. Article 11 is a strengthening of understanding that the right to a wholesome environment is a human right that gets protection from the constitution. This is confirmed in Article 25 states that all people have the right to maintain a minimum standard of healthy and cultured living. In all spheres of life, the State must use its endeavors to promote and expand social welfare and security, and public health. Japanese people believe that this right guaranteed by the constitution is a long struggle that cannot be contested. Article 97 emphasized that fundamental human rights have been guaranteed by the Japanese people as a human struggle to be free; they have survived various obstacles that demand endurance and given to present and future generations in trust, which will be held all time without being contested.

As well as in Indonesia, in the 1960s, Japan also faced many environmental problems and had not been able to guarantee the right to habitable and wholesome environment to the citizen. Japan be avowed as the most polluted state in the world due to rapid industrialization with a lack of pollution control. In early 1960s, Japan began to think about comprehensive pollution control policies. Several factors have accelerated their realization. People's dissatisfaction with the national environmental policy has arisen since the "big four" case and people are aware of the continuing problem of cross-border pollution involving several prefectures. ${ }^{46}$ These were the Kumamoto Minamata Disease (熊本水俣病 Kumamoto Minamata-byō) case ${ }^{47}$, the Toyama Itai-Itai Disease (富山イタイイタイ病

45 Leonard G. Ratner, "The Function of the Due Process Clause." University of Pennsylvania Law Review 116, no. 6 (1968): 1053-1057.

46 Shiro Kawashima, "A Survey of Environmental Law and Policy in Japan," J. Int'l L. \& Com 20 (1994).

47 Judgment of March 20, 1973, Kumamoto District Court, 696 判事 15 (Japan). See Julian Gresser et al., Environmental Law in Japan, (Cambridge: The M.I.T. Press. 1981) 65. Minamata's disease is caused by methylmercury waste from the Chisso Corporation chemical plant from 1932 to 1968. It was suspected that mercury sulfate in wastewater was metabolized to methylmercury by bacteria in the sediment. These highly toxic chemicals are accumulated and biomagnified in shellfish and fish in the Minamata Bay and Shiranui Sea. 
Toyama Itai Itai-byō) case ${ }^{48}$, the Niigata Minamata Disease (新潟 水俣病 Niigata Minamata-byō)case ${ }^{49}$ and the Yokkaichi Asthma (四日市ぜんそく Yokkaichi Zensoku) case ${ }^{50}$. In light of the importance of pollution prevention in ensuring the health and cultural life of the people, the responsibility for pollution prevention of business operators, national and local governments are clarified, and measures for pollution prevention are clarified. Enforcement of the basic provisions in the constitution is also emphasized. Therefore, Japan's environmental policy has been promoted based on two basic laws. One of them is the Basic Law on Environmental Pollution Control, which was enacted in 1967 to tackle serious industrial pollution that occurred in Japan in the period of rapid economic growth in the late 1950s and 1960s. The other is the Natural Environment Preservation Act, enacted in 1972 to dismiss the destruction of outstanding features of the natural environment. Established for the purpose of comprehensively promoting pollution control by prescribing basic matters, protecting the health of the people, and preserving the habitable environment.

The attitude of the Japanese government towards managing the global environment has changed rapidly. The government has introduced a variety of new environmental regulations aimed at resolving domestic and international pollution and promoting greater resource conservation. ${ }^{51}$ Since the early 1990s, environmental protection has become an increasingly important national and international policy and program for Japan. Japan

Local people poisoned from eating fish. While the deaths of cats, dogs, pigs and humans continued for 36 years, the government and companies did not make efforts to prevent pollution.

48 Judgment of June 30, 1971, Toyama District Court, 635 判事 17 (Japan). See Julian Gresser et al., op.cit, 49 , 55. The Toyama Itai-Itai Disease case is a case of cadmium poisoning which causes softening of bones, joints and chronic kidney disease. victims who suffer unbearable pain so often they shout "itai-itai" ("sick, sick"). for severe pain (Japanese: 痛 $い$ itai). Cadmium was released into the river by the Mitsui Mining and Smelting Company in the mountains, which was successfully prosecuted for pollution

49 Judgment of September 29, 1971, Niigata District Court, 642 判事 (Japan). See Kazumasa Takemori, Niigata Minamata Disease and Showa Denko, 中部大学産業経済研究所 紀要 第 22 号 2012 年 3, (22 Bulletin of Institute of Industrial Economy Chubu University, The Journal of Research Institute for Industry and Economics 56 (2012), Niigata Minamata Disease is a Minamata Disease occurred in Niigata Prefecture. Niigata Prefecture defines Minamata Disease is "a nervous disease with the nature of intoxication by eating fish contaminated by organic mercury repeatedly and continuously.

50 Judgment of July 24, 1972, Tsu District Court, Yokkaichi Branch, 672 判事 30 (Japan). The Yokkaichi Asthma is a case caused by air pollution as a result of burning oil and crude oil. large amounts of sulfur dioxide are released in the air which causes severe smog, which results in chronic obstructive pulmonary disease, chronic bronchitis, pulmonary emphysema, and bronchial asthma against the local people. Occured in the town of Yokkaichi in Mie Prefecture, Japan, between 1960 and 1972. See Julian Gresser, The Development of Pollution Control in Japan: An Historical Note, 1 Harv. Envtl. L. Rev. 541 (1976).

51 Miranda A. Schreurs, "Assessing Japan's Role as a Global Environmental Leader." Policy and Society 23, no. 1 (2004): 88-89. 
is one of 178 countries committed to the Rio Declaration on Environment and Development with the principles outlined in Agenda 21 to promote sustainable development at the United Nations Conference on Environment and Development (UNCED) 1992. ${ }^{52}$ Principle 7 of the Rio Declaration ${ }^{53}$ recognized the specific responsibility of developed countries in promoting environmental protection and development: "Developed countries recognize their responsibility in sustainable development given their community's pressure on the global environment and the technology and financial resources they command".

Japan is widely regarded as one of the developed countries with modern and progressive economic levels in the world in terms of its dedication to promoting environmental protection. In fact, Japan is very responsive to dealing with air pollution and the dangerous hazards associated with nuclear power plants. After years of change, beginning in the early 1990s, many new environmental laws were introduced, and new environmental institutions were established. Significant changes began to be made to national environmental law. 54

Basic Environmental Act was passed in 1993 replacing the Basic Act for Environmental Pollution Control of 1967 (as amended in 1970) and absorb the basic ideas of the 1972 Environmental Conservation Act. The new law is labeled "basic/fundamental" because it unites two different policies into one basic approach to preventing environmental pollution and preserving nature. It determines measures of environmental protection of the Japanese government by considering the modern global perspective. Importantly, this new action places responsibility on the government to protect not only the Japanese environment but the global environment. This was followed by the ratification of the Basic Environment Plan, which established policies and actions to reduce environmental impacts. Finally, Japan introduced the Environmental Impact Assessment Act in 1997. Other actions passed in recent years included a law requiring reporting the release of toxic chemicals into the environment and a law to promote green purchases. In the 2010 OECD report 55 , explained that Japan had made

52 Miranda A. Schreurs, ibid., 53.

53 See The Rio Declaration on Environment and Development (1992), available at http://www.unesco.org/education/pdf/RIO_E.PDF See in detail Review of Implementation of the Rio Principles, available at https://sustainabledevelopment.un.org/content/documents/1127 rioprinciples.pdf

54 Miranda A. Schreurs,op.cit., 95.

55 See OECD Environmental Performance Review: Japan 2010 available at https://www.oecd.org/env/oecd-environmental-performance-reviews-japan-2010-

9789264087873-en.htm. See also https://read.oecd-ilibrary.org/environment/oecdenvironmental-performance-reviews-japan-2010_9789264087873-en\#page1 DOI: https://dx.doi.org/10.1787/9789264087873-en 
significant environmental progress through a series of aggressive policies. In their report, the OECD stated that progress was made in terms of reducing air emissions, water use and municipal waste generation. In addition, it noted that Japan has made a conscious effort to move from a truly ecological sustainable development model to a broader approach that focuses on identifying existing relationships between ecological protection, economic growth, and social values.

\subsubsection{Equating Japan and Indonesia in protecting constitutional rights regarding and wholesome environment.}

Every state that constitutionally committed to the recognition of human rights determines the right to an adequate environment. This can be seen how Japan and Indonesia also provide protection to its citizens in the form of the realization of the right to habitable and wholesome environment not only listed in the constitution but also implemented through making various regulations in the field of the environment, protecting the environment and making environmental policy. Constitutional provisions relating to the environment not only in the form of provisions that are set forth in constitutional as fundamental rights but also how the constitution ensures the implementation of these provisions. Arrangements regarding the protection of the environment cannot be determined entirely in a constitution. constitution as a predominant regulation, thus, the elaboration of each article in the constitution can be stated in the form of Act and the implementation regulation of the Act as strengthening the realization of a law state that prioritizes the protection and law enforcement of the rights of its citizens.

\section{Conclusion}

Environmental protection is a joint responsibility of all Indonesian citizens, but the state has obligations and responsibilities under the constitution. The state was established to guarantee constitutional rights through the constitution. The constitution as a state foundation that is used as a guideline for state administration. The embodiment of the highest law must be obeyed by the state administrators and its citizens because the constitution was established as demand and expectation of the citizens to achieve justice. By mentioning as a constitutional state, citizens surrender rights to be regulated and implemented to ensure order for the state administrators.

In the Indonesian legal system, arrangements regarding the rights to acquire habitable and wholesome environment are contained in the constitution. This is the main protection given by the state to its citizens as an embodiment of citizens' constitutional rights. So that the existence of citizens' constitutional rights in the constitution is not a display to 
complement the Constitution of Indonesia 1945. Arrangements regarding environmental protection are not determined in detail directly in the constitution but explicitly regulate through articles in the constitution (article 28 letter $\mathrm{H}$ ) which instruct delegates to draft a legislation. As an implemented regulation of the constitution, the Act on the Environmental Protection and Management (The Act Number 32 Year 2009) became the basis for all laws and regulations relating to the environment. The description of the protection of citizens' constitutional rights regarding the right to habitable and wholesome environment has been implemented into the environment act. All provisions concerning the protection of the right to habitable and wholesome environment in detail have been set out therein. If this provision is carried out in accordance with the norms contained therein, then, surely the citizens' constitutional rights can be realized. In addition, even though based on Article 28 letter (I) paragraph (4) of the Constitution of Indonesia 1945 determined that the state, especially the government is obliged to respect, to protect and to fulfill in relation with the obligations that arise from human rights, every citizen also have to carry out the obligations and responsibilities together to overcome various environmental problems. In this way, the protection of the environment from a constitutional perspective can be strengthened.

\section{Books}

\section{Bibliography}

Asshidiqie, Jimly. Pengantar Imu Hukum Tata Negara. Jakarta: Konstitusi Press, 2006.

Assiddiqie, Jimly. Pengantar Ilmu Hukum Tata Negara, Cetakan Kedua. Jakarta: Rajawali Press, 2010.

Bradley, A.W. and Ewing, K.D. Constitutional and Administrative Law. (Pearson Education Limited 13 th ed. 2003).

Dean, Meryll. Japanese Legal System: Text and Material. Cavendish Publishing Limited, 1997.

Gresser, Julian et al., Environmental Law in Japan, Cambridge: The M.I.T. Press.,1981.

Hadjon, Phillipus M. Pengantar Hukum Administrasi Negara Indonesia. Yogyakarta: Gadjah Mada University Press, 2005.

Heinhard Steiger et.al., The Fundamental Right to a Decent Environment, Trends in Environmental Policy And Law (Tendances Actuelles De La Politique Et Du Droit De L'environnement), IUCN-WWF (project No. 1244) (1980).

Kelsen, Hans. General Theory of Law and State. New York: Anders Wedberg trans., Russell \& Russell, 1945.

Oda, Hiroshi. Japanese Law. New York, Oxford University Press $3^{\text {rd }}$ ed., 2009.

Palguna, I Dewa Gede. Pengaduan Konstitusional: Upaya Hukum Terhadap 
Pelanggaran Hak-Hak Konstitusional Warga Negara. Jakarta: Sinar Grafika, 2013

Plato. The Laws of Plato. London: Thomas L. Pangle trans., The University of Chicago Press, 1980.

Paine, Thomas. The Rights of Man 1971-1972. ed. H Collins, Penguin Classics, 1969.

Plato. The Republic of Plato. London: Francis Macdonald Cornford trans, Oxford University Press, 1941.

James R. Silkenat, James E. Hickey Jr., Peter D. Barenboim eds., The Legal Doctrines of the Rule of Law and the Legal State (Rechsstaat), Switzerland: Springer, 2014.

Venn Dicey, Albert. Introduction to the Study of the Law of the Constitution. London: Macmillan, 8th ed. 1915.

Wheare, K.C. Modern Constitutions. New York: Oxford University Press, $2^{\text {nd }}$ ed., 1966.

\section{Chapter in an Edited Book}

Ito M, "The Modern Development of Law and Constitution in Japan," in Japan Legal System: Text and Material, edited by Meryll Dean. London: Cavendish Publishing Limited, 1997.

\section{Journal Articles}

Gardbaum, Stephen. "Human Rights as International Constitutional Rights." European Journal of International Law 19, no. 4 (2008): 749-768. https://doi.org/10.1093/ejil/chn042

Gardbaum, Stephen. "The" Horizontal Effect" of Constitutional Rights." Michigan Law Review 102, no. 3 (2003): 387-459.

Gresser, Julian. The Development of Pollution Control in Japan: An Historical Note, 1 Harv. Envtl. L. Rev 1 (1976).

Hildebrandt, Mireille. "Justice and Police: Regulatory Offenses and the Criminal Law." New Criminal Law Review: In International and Interdisciplinary Journal 12, no. 1 (2009): 43-68. https: / / doi.org/10.1525/nclr.2009.12.1.43

Jr. John Y. Pearson , "Toward a Constitutionally Protected Environment." Virginia Law Review (1970): 458-486. https: / / doi.org/10.2307/1071799

Klipsch, Ronald E. "Aspects of a Constitutional Right to a Habitable Environment: Towards an Environmental Due Process," Ind. L.J. 49, (1974): 203-237.

Kawashima, Shiro. "A Survey of Environmental Law and Policy in Japan N.C.” J. Int'l L. \& Com 20 (1994): 232-254

Neuman, Gerald L. Human Rights and Constitutional Rights: Harmony and Dissonance Stan. L. Rev. 55 (2003): 1863-1900.

Ratner, Leonard G. "The Function of the Due Process Clause." University of Pennsylvania Law Review 116, no. 6 (1968): 1048-1117. https://doi.org/10.2307/3311120

Rosenfeld, Michel. The Rule of Law and the Legitimacy of Constitutional 
Democracy, S. Cal. L. Rev. 74 (2001) 1307-1352

Schreurs, Miranda A. "Assessing Japan's Role as a Global Environmental Leader." Policy and Society 23, no. 1 (2004): 88-110. https://doi.org/10.1016/S1449-4035(04)70028-4

TAKEMORI, Kazumasa. "Niigata Minamata Disease and Showa Denko (産業 経済研究所設立 30 周年記念号)." 産業経済研究所紀要 22 (2012): 53-80.

Zen, Nilwan Wilze Ananda, Untung Dwi Hananto, and Amalia Diamantina Jaminan Hak-Hak Konstitutional Warga Negara (the Protector of Citizen Constitutional Right) dengan Implementasi Constitutional Complaint Melalui Mahkamah Konstitusi di Negara Republik Indonesia, Diponegoro L. Rev 5, no. 2 (2016): 1-24.

\section{Website Contents}

Japan

Basic

Environmental

Law.

https://www.env.go.jp/en/laws/policy/basic/index.html

Dinah Selton, Stockholm Declaration (1972) and Rio Declaration (1992), OXFORD PUBLIC INTERNATIONAL LAW.

http:/ / opil.ouplaw.com/view/10.1093/law:epil/9780199231690/law978019 9231690-e1608\#law-9780199231 690-e1608-div1-2

The Ministry of Foreign Affairs of Japan, Human Rights, Humanitarian Assistance, https://www.mofa.go.jp/policy/human/index.html

Refugees,

The Rio Declaration on Environment and Development (1992), http://www.unesco.org/education/pdf/RIO_E.PDF

The Universal Declaration of Human Rights (UDHR), www.un.org/en/universal-declaration-human-rights/

OECD Environmental Performance Review: Japan 2010. Last Modified November 16, 2010. https://www.oecd.org/env/oecd-environmentalperformance-reviews-japan-2010-9789264087873-en.htm. See also https:// read.oecd-ilibrary.org/environment/oecd-environmentalperformance-reviews-japan-2010_9789264087873-en\#page 1

Review of Implementation of the Rio Principles, https://sustainabledevelopment.un.org/content/documents / 1127 rioprinciples.pdf

\section{Working Paper}

Dinah Selton, Human Rights, Health \& Environmental Protection: Linkages in Law \& Practice, Health and Human Rights Working Paper Series No 1 A Background Paper for the World Health Organization (WHO)

\section{Legal Documents}

The International Covenant on Economic, Social and Cultural Rights (ICESCR)

The United Nations Conference on the Human Environment (UNCHE)

The Republic of Indonesia, The Constitution of Indonesia 1945

The Federal Republic of Indonesia, The Federal Constitution 1949 
The Republic of Indonesia, The Provisional Constitution 1950

The Republic of Indonesia, The Act No. 4 Year 1982 concerning The Basic Provisions of Environmental Management

The Republic of Indonesia, The Act No. 23 Year 1997 concerning The Environmental Management.

The Republic of Indonesia, The Act Number 32 Year 2009 concerning The Environmental Protection and Management.

The Constitution of Japan (Shinjitai: 日本国憲法 Kyūjitai: 日本國憲法 NihonKoku Kenpō) 1947 